\title{
Outcomes of Amputations Versus Limb Salvages Following Military Lower Extremity Trauma
}

\author{
R. A. Hayda ${ }^{1}$, W. C. Doukas ${ }^{2}$, R. C. Andersen ${ }^{3}$, J. R. Ficke ${ }^{4}$ \\ ${ }^{1}$ Rhode Island Hospital, Brown University, Providence. USA \\ ${ }^{2}$ United Hospital Center Orthopedics, Bridgeport. USA \\ ${ }^{3}$ Walter Reed National Military Medical Center, Washington. USA \\ ${ }^{4}$ San Antonio Military Medical Center, Fort Sam Houston. USA
}

Objective: to examine the hypothesis that functional outcomes following major lower-extremity trauma sustained in the military would be similar between patients treated with amputation and those who underwent limb salvage. Methods: this is a retrospective cohort study of 324 service members deployed to Afghanistan or Iraq who sustained a lower-limb injury requiring either amputation or limb salvage involving revascularization, bone graft/bone transport, local/free flap coverage, repair of a major nerve injury, a complete compartment injury/compartment syndrome. The Short Musculoskeletal Function Assessment (SMFA) questionnaire was used to measure overall function. Standard instruments were used to measure depression (the Center for Epidemiologic Studies Depression Scale), posttraumatic stress disorder (PTSD Checklist-military version), chronic pain (Chronic Pain Grade Scale), and engagement in sports and leisure activities (Paffenbarger Physical Activity Questionnaire). The outcomes of treatment were compared by using regression analysis with adjustment for age, time until the interview, military rank, upper-limb and bilateral injuries, social support, and intensity of combat experiences. Results: overall response rates were modest (59.2\%) and significantly different between those who underwent amputation (64.5\%) and those treated with limb salvage (55.4\%) ( $p=0.02)$. Also, $38.3 \%$ screened positive for depressive symptoms and $17.9 \%$, for posttraumatic stress disorder (PTSD). One-third (34.0\%) were not working, on active duty, or in school. After adjustment for covariates, participants with an amputation had better scores in all SMFA domains compared with those whose limbs had been salvaged $(p<0.01)$. They also had a lower likelihood of PTSD and a higher likelihood of being engaged in vigorous sports. Conclusions: major lower-limb trauma sustained in the military results in significant disability. Service members who undergo amputation appear to have better functional outcomes than those who undergo limb salvage. Caution is needed in interpreting these results as there was a potential for selection bias. Key words: military lower limb trauma, amputation, limb salvage, depression, stress.
Цель: провести сравнительную оченку результатов лечения военнослужащих с травмами нижних конечностей, полученных в результате военных действий, после ампутаций и органосохраняющих конечность операций (ОКО). Методы: ретроспективное исследование включало 324 военнослужаших армии США, получивщих травмы во время военных действий в Афганистане или Ираке, которым выполнены ампутации или ОКО с применением реваскуляризачии, костной пластики, транспозиции кожно-мышечных лоскутов, пластики магистральных нервных стволов и лечения компартмент-синдрома. Функииональные результаты оценивали с помощью шкаль SMFA (Short Musculoskeletal Function Assessment). Анализировали также степень деnpeccuu (Center for Epidemiologic Studies Depression Scale), посттравматические стрессовые расстройства (ПСР) по опроснику Checklist-military Version, хронические боли (Chronic Pain Grade Scale), спортивная и повседневная активность (Paffenbarger Physical Activity Questionnaire). Результаты анализировали с учетом возраста, времени после ранения, воинского звания, сочетанных травм верхних и нижней конечностей, сочиальной поддержки и предшествуюшего опыта боевых действий. Результаты: общий прочент ответивших был 59,2\% и значительно $(p=0,02)$ отличался в группе с ампутациями (64,5\%) и ОКО (55,4\%). У 38,3 \% исследованных зафиксированы выраженные симптомы депрессии, у 17,9\% - ПСР. Не работали или не продолжали обучение 34,0 \% пострадавших. У военнослужащих после ампутаций конечностей получены лучшие результаты по всем разделам шкаль SMFA по сравнению с теми, у кого конечности сохранены $(p<0,01)$. Они также имели более низкую вероятность развития ПСР и более высокие возможности заниматься спортом. Выводы: большинство травм нижних конечностей, полученных в результате боевых действий, приводят к значительной инвалидности. Раненные после ампутации имеют лучшие отдаленные функциональные результаты, чем пострадавшие после ОКО. Результаты необходимо интерпретировать с осторожностью из-за возможных отклонений в чистоте отбора пациентов. Ключевые слова: военная травма нижней конечности, ампутация, органосохраняющая операщия, депрессия, стресс. 
Key words: military lower limb trauma, amputation, limb salvage, depression, stress

\section{Introduction}

Extremity trauma resulting from high-energy explosives in Iraq and Afghanistan is common; $54 \%$ of evacuated wounded service members have extremity injuries. More than one-quarter $(26 \%)$ of all extremity war injuries involve fractures; $82 \%$ of these are open $[1,2]$. Current treatment of extremity war injuries initially involves resuscitation and excision of devitalized tissue. Fractures are stabilized in preparation for evacuation. The casualties arrive at definitive care facilities, where they receive definitive management with amputation or limb reconstruction, in as few as seventy-two hours postinjury.

Little is known about the long-term results of these treatments in the military - specifically whether the outcomes of amputation and reconstruction are comparable. Results from the Lower Extremity Assessment Project (LEAP) suggest that the functional outcomes of reconstruction and amputation are similar in civilians being treated for major lower-extremity trauma [3-6]. Regardless of the type of treatment, LEAP outcomes were not optimal, with one-half of injured civilians reporting high levels of disability. However, these results may not be generalizable to the military. The mechanisms of injury are different, with blasts generating $79 \%$ of combat casualties compared with a predominance of blunt mechanisms in civilian trauma. Access to rehabilitation and prosthetic services is likely more uniform in the military. In addition, soldiers have better preinjury physical conditioning, higher levels of self-efficacy, and a robust support network, all of which correlate with better outcomes. The rate of posttraumatic stress disorder (PTSD), on the other hand, may be higher among military than civilian trauma patients.

The objective of this study was to examine functional outcomes and disability following major lower-extremity trauma sustained in the military and to compare the outcomes between patients treated with amputation and those treated with limb salvage. On the basis of existing civilian studies, we hypothesized that the outcomes are similar for the two treatment groups.

\section{Material and methods}

The Military Extremity Trauma Amputation/Limb Salvage (METALS) study is a retrospective cohort study of U.S. service members who sustained a major limb injury while serving in Afghanistan or Iraq between 2003 and 2007. Potentially eligible participants were identified retrospectively from the following U.S. military treatment facilities: Walter Reed National Military Medical Center, San Antonio Military Medical Center, and Naval Medical Center San Diego. Patients meeting the screening criteria were sent a letter describing the study and asked for permission to be telephoned. Those who did not refuse were contacted by Social \& Scientific Systems, Inc., who obtained consent to conduct an interview and abstract their medical records. Interviews were completed by trained interviewers, and medical records were abstracted by nurses trained specifically for the METALS study. Eligibility criteria were confirmed on review of the medical record. The study was approved by the institutional review boards of each military treatment facility, the Johns Hopkins Bloomberg School of Public Health (the study coordinating center), and the U.S. Army Medical Research and Materiel Command.

\section{Study Population}

Eligible for participation in the study were active duty personnel and reservists deployed to Afghanistan or Iraq who had sustained an injury to the upper or lower limb (excluding the pelvis/acetabulum) that resulted in a major am-putation (at or proximal to the hindfoot or the radiocarpal joint) or required operative treatment and revascularization, bone-grafting/bone transport, local/free flap coverage, repair of a major nerve injury, or treatment of a complete compartment injury/compartment syndrome. These injuries typically included traumatic amputations, Gustilo Type-IIIB and IIIC fractures, selected Type-IIIA fractures, dysvascular limbs, major softtissue injuries, and severe foot and hand injuries. Excluded were patients with a Glasgow Coma Scale score of $<15$ at discharge or a spinal cord injury.

A total of 868 service members met the screening criteria and were located at an average of 38.6 months (range, 6.8 to 69.7 months) postinjury. Of these, 519 (59.8\%) consented to an interview, 202 (23.3\%) refused to participate, and 147 (16.9\%) were called multiple times but never reached. The percentage with completed interviews was higher among those who underwent an amputation (64.5\%) compared with those treated with a limb salvage procedure $(55.4 \%)(p=0.02)$. Common reasons for refusing to participate included «just not interested» $(50 \%)$ and «no time; too time-consuming» (9\%). Of the 519 who consented, sixty-nine did not meet the eligibility criteria on review of the medical record and medical records were not located for twenty-one patients, 
leaving 429 service members with complete information. For this paper, we focused on 324 individuals who had sustained eligible injuries to the lower limbs (the remaining 105 had injuries to the upper limbs only) (table 1).

\section{Measuring Outcomes}

Outcomes were measured with use of the following self-report instruments:

- The Short Musculoskeletal Function Assessment (SMFA) questionnaire was used for measuring functional status [7]. It provides an overall score and subscores summarizing dysfunction in four domains: mobility, arm/hand function, daily activities, and emotional status.

- The Paffenbarger Physical Activity Questionnaire [8] was used to determine participation in sports/leisure activities. We asked respondents to identify up to five activities performed within the past three months. The 2000 version of the Compendium of Physical Activities [9] was used to classify each activity according to the rate of energy expenditure expressed as metabolic equivalents (METS). Activities were classified as light ( $<3$ METS), moderate (3 to 6 METS), or vigorous ( $>6$ METS) [10].

- Participation in a major role activity was assessed with use of standard questions about usual activity in the past week (e.g., active duty, work, school, taking care of home).

- The Revised Center for Epidemiologic Studies Depression Scale (CESD-R) [11] was used to detect depressive symptoms. We classified respondents with CESD-R scores of $>16$ as having clinically relevant symptoms of depression and scores of $>21$ as having major depression [12].

- The military version of the PTSD Checklist (PCL) [13] was used for assessing symptoms consistent with a diagnosis of PTSD. Respondents were identified with probable PTSD if they had (1) experienced at least one re-experiencing/intrusive symptom, at least three avoidance experiences, and at least one symptom of hyperarousal, all at the moderate or extreme level (a score of $>3$ ) and (2) reported substantial distress as indicated by a total PCL score of $>50$ [14].

- The Chronic Pain Grade (CPG) scale [15] was used to grade the severity of chronic pain. For the analysis, we examined the presence of pain interfering with daily activities (pain interference).

\section{Measuring Covariates}

Participants were characterized (at the interview) by age, sex, race/ethnicity, military service and grade (highest on active duty), education, marital status, and perceived adequacy of social support with use of the Multidimensional Scale of Perceived Social
Support [16]. Also, a measure of combat experiences was ascertained with use of the Combat Experiences Questionnaire (CEQ) [17].

Injuries were classified on the basis of information in the medical record of the echelon-five (stateside) military treatment facility. Fractures treated with limb salvage were classified by bone segment and AO/OTA classification [18]. Also documented were segmental loss, skin defects, burns, extent of muscle/tendon injury, and location/severity of all nerve and vascular injuries. Amputations were classified by level.

\section{Statistical Analysis}

Outcomes were first compared across five principal groups: (1) unilateral sal-vage, (2) unilateral amputation, (3) bilateral amputation, (4) bilateral salvage, and (5) bilateral with amputation on one side and salvage on the other (Table 2). Multiple regression techniques were used to examine differences in outcomes of am-putation versus salvage while adjusting for characteristics of the patients and their injuries, together with the time since the injury. Linear regressions were used to model continuous SMFA scores and logistic regressions, to model the probability of dichotomous outcomes.

Outcomes were modeled in two ways. First, we modeled them as a function of four dichotomous variables that categorized respondents into the five analysis groups defined above. As an alternative, we included «any amputation» as the main independent variable and adjusted for bilateral versus unilateral injuries by including the appropriate dichotomous variable and interaction term. The results were the same with use of either approach; for simplicity of interpretation, we present the results using the dichotomous variable for «any amputation». Regressions were also performed with and without inclusion of patients with a METALS-eligible injury to the upper limbs (including eight resulting in a major amputation); the results were the same. Results including all patients and adjusting for the presence of upperlimb injuries are presented.

Regressions were also performed to separately explore correlates of outcome for those with and those without an amputation. These regressions included the covariates defined above together with (1) level of amputation and early versus delayed (more than ninety days) amputation (for amputees) or (2) number of bone segments fractured and whether procedures were performed for revascularization, bone-grafting or bone transport, local or free flap coverage, repair of major nerve injury, or complete compartment injury/compartment syndrome (for patients treated with limb salvage). 
Characteristics of Participants by Presence of Bilateral Injury and Salvage Versus

\begin{tabular}{|c|c|c|c|c|}
\hline \multirow[t]{2}{*}{ Index } & \multirow{2}{*}{$\begin{array}{l}\text { All Participants } \\
\quad(\mathrm{N}=324)\end{array}$} & \multicolumn{2}{|c|}{ Unilateral Lower-Limb Injury } & \multirow{2}{*}{$\begin{array}{l}\text { Bilateral Lower-Limb } \\
\text { Injury }(\mathrm{N}=85)\end{array}$} \\
\hline & & $\begin{array}{c}\text { Salvage } \\
(\mathrm{N}=126)\end{array}$ & $\begin{array}{l}\text { Amputation } \\
(\mathrm{N}=113)\end{array}$ & \\
\hline Mean time to interview (mo) & 37.5 & 39.5 & 37.4 & 34.8 \\
\hline \multicolumn{5}{|l|}{ Age $(\%)$} \\
\hline $18-24$ yr & 24.2 & 24.0 & 26.5 & 21.2 \\
\hline $25-29 \mathrm{yr}$ & 36.2 & 35.2 & 36.3 & 37.6 \\
\hline $30 \mathrm{yr}$ & 39.6 & 40.8 & 37.2 & 41.2 \\
\hline Male $(\%)$ & 97.2 & 97.0 & 98.2 & 98.8 \\
\hline \multicolumn{5}{|l|}{ Race/ethnicity (\%) } \\
\hline Non-Hispanic white & 71.6 & 81.8 & 75.9 & 69.1 \\
\hline Non-Hispanic black & 7.5 & 18.2 & 6.2 & 8.3 \\
\hline Hispanic & 15.9 & 0.0 & 17.0 & 13.1 \\
\hline Other & 5.0 & 0.0 & 0.9 & 9.5 \\
\hline High school or less (\%) & 36.1 & 41.3 & 27.4 & 40.0 \\
\hline \multicolumn{5}{|l|}{ Marital status (\%) } \\
\hline Married & 57.7 & 54.8 & 54.9 & 65.9 \\
\hline Never married & 28.7 & 30.9 & 30.1 & 23.5 \\
\hline Separated/divorced/widowed & 13.6 & 14.3 & 15 & 10.6 \\
\hline \multicolumn{5}{|l|}{ Social support[16] (\%) } \\
\hline Low $(0-70)$ & 26.8 & 31.8 & 27.5 & 18.8 \\
\hline Moderate (71-80) & 35.8 & 34.9 & 34.5 & 38.8 \\
\hline High $(81-100)$ & 37.4 & 33.3 & 38.0 & 42.4 \\
\hline \multicolumn{5}{|l|}{ Military grade (\%) } \\
\hline Junior enlisted (E1-E4) & 33.4 & 36.8 & 31.0 & 31.8 \\
\hline Mid to senior enlisted (E5-E9) & 46.5 & 40.8 & 48.7 & 51.8 \\
\hline Officer & 20.1 & 22.4 & 20.3 & 16.4 \\
\hline \multicolumn{5}{|l|}{ Combat experiences [17] (\%) } \\
\hline $1-5$ & 17.6 & 15.1 & 17.7 & 21.2 \\
\hline $6-8$ & 20.1 & 19.1 & 18.6 & 23.5 \\
\hline $9-11$ & 25.6 & 25.4 & 29.2 & 21.2 \\
\hline $12-17$ & 36.7 & 40.4 & 34.5 & 34.1 \\
\hline
\end{tabular}

\section{Results and disscussion}

\section{Characteristics of Study Participants}

The majority of the study participants were active-duty Army (65\%) or Marines (24\%) personnel; $7 \%$ were reservists. The characteristics of the study participants according to amputation versus limb salvage and unilateral versus bilateral injury were similar with one exception (table 1). The percentage of patients who reported having a high-school education or less was smaller in the unilateral amputation group $(27.4 \%)$ compared with the unilateral salvage group $(41.3 \%)$ and the patients with bilateral injuries $(40.0 \%)(\mathrm{p}=0.06)$. Participants were interviewed at an average of 37.5 months postinjury. Only four participants were evaluated at less than one year after the injury.

\section{Characteristics of the Injury}

A total of 239 patients sustained an eligible injury to one limb and eighty-five, to both limbs. At the time of the interview, 182 participants had undergone an amputation (thirty-nine bilaterally) and 142 had had limb salvage without an amputation. Of the 182 participants with an amputation, $14.1 \%$ had a delayed amputation (at greater than ninety days). Of all 221 amputations of a lower limb, eighty-one (36.7\%) were transfemoral and 115 $(52.0 \%)$ were transtibial; there were nine hip disarticulations, twelve knee disarticulations, three Syme amputations, and one Chopart disarticulation. Cha- 
Outcomes of Participants by Amputation Status and Unilateral Versus Bilateral

\begin{tabular}{|c|c|c|c|c|c|c|}
\hline \multirow[t]{2}{*}{ Index } & \multirow[t]{2}{*}{ All Patients } & \multicolumn{2}{|c|}{ Unilateral Lower-Limb Injury } & \multicolumn{2}{|c|}{ Bilateral Lower-Limb Injury } & \multirow{2}{*}{$\begin{array}{l}\text { Bilateral } \\
\text { Salvage }\end{array}$} \\
\hline & & Amputation & Salvage & $\begin{array}{c}\text { Bilateral } \\
\text { Amputation }\end{array}$ & $\begin{array}{l}\text { Amputation } \\
\text { and Salvage }\end{array}$ & \\
\hline No. of participants & 324 & 113 & 126 & 39 & 30 & 16 \\
\hline \multirow{2}{*}{$\begin{array}{l}\text { Mean SMFA scores (points) } \\
\text { Total dysfunction Daily activities }\end{array}$} & 25.6 & 21.8 & 29.8 & 22.2 & 24.0 & 30.0 \\
\hline & 24.6 & 20.6 & 27.9 & 22.8 & 27.3 & 26.8 \\
\hline \multirow{2}{*}{ Emotional status Arm/hand function Mobility } & 41.0 & 38.2 & 47.8 & 33.2 & 31.7 & 44.4 \\
\hline & 5.2 & 2.0 & 8.1 & 3.0 & 5.2 & 10.0 \\
\hline \multirow{2}{*}{ Engaged in vigorous sports or recreational activities (\%) } & 32.7 & 27.9 & 37.2 & 30.2 & 30.8 & 40.3 \\
\hline & 38.0 & 45.1 & 26.2 & 48.7 & 50.0 & 31.2 \\
\hline With depressive symptoms (\%) & 38.3 & 40.7 & 43.6 & 25.6 & 23.3 & 37.5 \\
\hline $\begin{array}{l}\text { With possible/probable major } \\
\text { depression }(\%)\end{array}$ & 13.0 & 13.3 & 15.1 & 10.3 & 6.7 & 12.5 \\
\hline Screened positive for PTSD (\%) & 17.9 & 14.8 & 26.8 & 10.3 & 6.4 & 12.5 \\
\hline Working/on active duty (\%) & 43.7 & 43.4 & 48.0 & 30.8 & 36.7 & 56.2 \\
\hline In school (\%) & 22.3 & 29.2 & 18.4 & 17.9 & 6.6 & 6.3 \\
\hline With pain interfering with daily activity (\%) & 19.9 & 17.1 & 27.0 & 10.3 & 16.7 & 12.5 \\
\hline
\end{tabular}

racteristics of the salvaged limbs are summarized in the Appendix. Sixteen percent of the participants had a METALS-eligible upper-limb injury (including eight major amputations).

Outcomes at the Time of Follow-up Overall, participants reported moderate-to-high levels of disability (table 2). In all domains of the SMFA except arm/hand function, patients scored significantly higher (worse function) than population norms, which have been reported to be 12.7 for total dysfunction, 13.6 for mobility, 11.8 for daily activities, 20 for emotional status, and 6.0 for arm/hand function [19]. Of particular note are the high scores for mobility (32.7) and emotional status (41.0) in the present study. Overall, $38.0 \%$ reported being engaged in vigorous sports or recreational activities.

More than one-third of the participants (38.3\%) reported symptoms consistent with probable depression; $13.0 \%$ had scores indicative of major depression. Nearly one-fifth (17.9\%) screened positive for PTSD. Less than one-half (43.7 \%) were working or on active duty at the time of the interview. However, an additional $22.3 \%$ were going to school. Onefifth $(19.9 \%)$ of the respondents indicated that pain interfered with their normal activities.

\section{Comparison of Outcome by Treatment}

The outcomes of the injury are summarized according to amputation versus limb salvage and unilateral versus bilateral in table 2; regression results are presented in the Appendix. Race/ethnicity was dropped from the final model as it was not a significant predictor in any regression analysis. Education was also dropped as it was correlated with military pay grade. In addition, education was assessed at the time of the interview and thus could not be appropriately viewed as predictor of outcome. The interaction between amputation status and the presence of bilateral lower limb injuries was not significant $(\mathrm{p}>0.16)$.

After adjustment for covariates, patients with any amputation had significantly lower scores (better functioning) in all domains of the SMFA compared with patients with limb salvage $(\mathrm{p}<0.01)$. To highlight the differences in scores by amputation status, the mean adjusted scores (derived from the regression model incorporating the five analysis subgroups) are presented in table 3 for the study subgroups defined by amputation status and presence of bilateral injuries. Even pa-tients who had one or both legs amputated trended toward having better function than those with unilateral limb salvage, although the differences were not always significant.

Compared with patients whose limbs had been salvaged, those with an amputation were 2.6 times more likely to engage in vigorous activity and $57 \%$ less likely to screen positive for PTSD. There were no differences based on amputation status in the probability of screening positive for depression or of having pain interference, or in the percentage working/on active duty or in school at the time of the interview.

Other Factors Correlated with Outcomes Several other factors influenced outcomes. Older age was associated with higher (worse) total SMFA scores and all component SMFA scores $(\mathrm{p}<0.01)$ and with a higher 
Adjusted Mean SMFA Scores by Amputation Status and Unilateral Versus Bilateral Lower-Limb Injury

\begin{tabular}{|l|c|c|c|c|c|}
\hline \multicolumn{5}{|c|}{ Adjusted Mean SMFA Scores by Amputation Status and Unilateral Versus Bilateral Lower-Limb Injury * } \\
\hline \multirow{2}{*}{ Index } & \multicolumn{2}{|c|}{ Unilateral Lower-Limb Injury Amputation Salvage } & \multicolumn{3}{c|}{ Bilateral Lower-Limb Injury } \\
\cline { 4 - 6 } & & 126 & Bilateral Amputation & Amputation and Salvage & Bilateral Salvage \\
\hline No. of participants & 113 & 39 & 30 & 16 \\
\hline Adjusted SMFA scores: & $21.5 \mathrm{f}$ & 29.8 & 22.2 & $24.0 \mathrm{f}$ & 30.0 \\
\hline Total dysfunction & $27.5 \mathrm{f}$ & 37.2 & 30.2 & $30.8 \mathrm{f}$ & 40.3 \\
\hline Mobility & $20.4 \mathrm{f}$ & 27.9 & 22.8 & 27.5 & 26.8 \\
\hline Daily activities & $37.6 \mathrm{f}$ & 47.9 & $33.2 \mathrm{f}$ & $32.0 \mathrm{f}$ & 44.4 \\
\hline Emotional status & $2.1 \mathrm{f}$ & 8.2 & $3.0 \mathrm{f}$ & 3.1 & 10.0 \\
\hline Arm/hand function & & & & & \\
\hline
\end{tabular}

Coments. * - Adjusted for the presence of METALS-eligible upper-limb injury, presence of bilateral lower-limb injury, months until interview, age, military rank, intensity of combat experiences, and presence of social support. Significantly different $(\mathrm{p}<0.01)$ from patients with unilateral salvage. Significantly different $(\mathrm{p}<0.05)$ from patients with unilateral salvage.

risk of pain interference $(\mathrm{p}<0.05)$. Patients who were interviewed at a longer time from their injury had better mobility and performance of daily activities ( $\mathrm{p}<0.01)$; they were also more likely to be working/on active duty or in school $(\mathrm{p}<0.01)$. The presence of a major upper-limb injury was associated with significantly worse scores for hand/arm function $(p<0.01)$ but was not correlated with other outcomes.

Higher military rank was positively correlated with a lower probability of depression $(p<0.01)$ and PTSD $(\mathrm{p}<0.05)$ and with a higher probability of working/on active duty or in school $(\mathrm{p}<0.05)$ and being engaged in vigorous activities $(\mathrm{p}<0.01)$. More intense combat experiences were associated with worse scores on the SMFA (except for daily activities and hand/arm function) and a higher likelihood of PTSD. Finally, the strength of social support was a strong and consistent correlate of both physical and psychosocial functioning except for engagement in vigorous activity $(\mathrm{p}<0.01)$.

Neither the level nor the timing of the amputation was significantly associated with the outcomes in the amputee group. The regressions for the unilateral salvage group showed no differences in outcomes based on number of bone segments injured, location of the injury (tibia, femur, or foot; diaphyseal versus metaphyseal), or number of METALS criteria met.

This analysis provides one of the first assessments of long-term outcomes following major limb trauma sustained in recent U.S. armed conflicts. Overall, participants in the study reported moderateto-high levels of both physical and psy-chosocial disability. Not only were the SMFA mobility scores high (more disability), the SMFA scores assessing emotional status were high, as were the percentages of participants who screened positive for de- pression and PTSD. These results mirror those found for injured civilians in the LEAP study [3-6]. LEAP participants scored significantly worse than population norms on the Sickness Impact Profile, a generic measure of functioning similar to the SMFA in content $[3,4]$. Nearly $40 \%$ of both METALS and LEAP participants reported symptoms of depression (37.6 \% at two years in the LEAP study, as measured with the Brief Symptom Inventory) [5]. Although PTSD was not specifically measured in the LEAP study, $29.4 \%$ of participants reported symptoms of generalized anxiety [5]. The percentage working among the METALS participants (43.7\%) was lower than that among the LEAP participants $(55 \%$ and $62 \%$ at twenty-four and eighty-four months, respectively) [6]. However, $22.3 \%$ of the METALS participants were going to school (compared with only $3 \%$ of the LEAP participants). This difference likely reflects both the younger age of the METALS cohort (64\% compared with $40 \%$ were thirty years old or more in the LEAP and METALS cohorts, respectively) as well as veterans' access to generous educational benefits. Our results are similar to those of Reiber et al. [20], who found that, of 317 Operation Iraqi Freedom/Operation Enduring Freedom service members and veterans who underwent a unilateral lowerlimb amputation, $57 \%$ were employed and $22 \%$ were in school one year postinjury.

While few studies have examined overall functioning following extremity trauma resulting from highenergy-blast and ordnance-related mechanisms, there have been several reports documenting the prevalence of PTSD and depression among soldiers and Marines deployed to Iraq or Afghanistan. Rates of PTSD and depression vary by the definition used, when it is measured, and the population studied [14, 17, 21-32]. Two 
studies provide some basis for comparison. Using the same criteria as utilized in the METALS study, Hoge et al. reported a PTSD prevalence of $23.9 \%$ and $9.1 \%$ among injured and uninjured soldiers, respectively, three to four months following their return from a yearlong deployment to Iraq [21]. The prevalence of major depression (measured with the Patient Health Questionnaire) was 9.6\% for injured soldiers and $3.3 \%$ for those not injured. Grieger et al. [28] found that $12.0 \%$ of 301 soldiers who had life-threatening or seriously disfiguring in $\neg$ juries screened positive for PTSD (measured with the same criteria as used in the METALS study) seven months postinjury; $9.3 \%$ screened positive for major depression (measured with the Patient Health Questionnaire). Our estimates of $17.9 \%$ screening positive for PTSD and $13.0 \%$ having a pos-sible/probable diagnosis of major depression are comparable with the values in these studies and underscore the substantial mental health consequences of major lower-limb trauma.

We found that participants with a untfateral or bilateral amputation had significantly better SMFA functional outcomes than those whose limbs had been salvaged. This result is contrary to what was found in the civilian LEAP study[3, 4], where there were no significant differences in outcomes at two or seven years postinjury We also found that amputees were nearly three times more likely to be engaged in a vigorous sports or recreational activity. However, the percentage working/on active duty or in school was the same, as were the rates of depressi $\mathrm{H}$ Interestingly, patients with bilateral METALS-eligible injuries had outcomes comparable with those with unilateral injuries, except for the outcome of role participation. Persons with bilateral injuries were $56 \%$ less likely to be working/on active duty or going to school than those with unilateral injuries $(\mathrm{p}<0.01)$.

One can only conjecture as to the possible reasons for the marked differences in outcomes. Military amputees may receive more focused rehabilitation early in their recovery (compared with both military persons with limb salvage and civilian amputees). The military has historically organized specialized amputee rehabilitation centers when at war, as this has remained true for the conflicts in Afghanistan and Iraq. Weight-bearing is allowed as soon as there is sufficient wound-healing. Amputees in the military often spend more than one year in rehabilitation in residence at the military treatment facility (or nearby), have ready access to prosthetists, and benefit from targeted reintegration programs. In contrast, patients treated with limb salvage may need to wait three or more months before full weight-bearing is allowed to provide time for articular fractures and bone defects to heal. The patients do receive therapy but in a less organized fashion, undergoing progressive rehabilitation to achieve maximal rehabilitation prior to returning to full duty or medical separation. In contrast, very few civilians (18\%) who lose a leg due to trauma are hospitalized for rehabilitation [33]. Furthermore, the amount of both outpatient and inpatient rehabilitation received by civilians who have had an amputation is highly dependent on insurance coverage.

Because of the visible nature of their injury, military amputees (compared with patients who have undergone limb salvage) may also receive more attention overall or bond with others with similar injuries. In addition, they may have greater access to peer and external support early in their recovery, which may in turn result in better outcomes. These support services are generally less available to civilians.

Another factor that might explain differences in outcome is that military amputees have access to state-of-the-art prosthetic devices and prosthetic care [34-36]. Inadequate insurance coverage often limits the type and number of prostheses that civilian amputees receive. Furthermore, contemporary advanced rehabilitation and prosthesis management are not often available for civilians who have had an amputation.

As with any observational study, limitations must be taken into account when interpreting our results. First, this is a cross-sectional study in which outcomes were assessed at an average of thirty-eight months postinjury. While the time since the injury was taken into account in the analysis, unifom timing of the outcome assessment limits our ability to establish causal relationships. In addition, all outcomes were based on self-report. Although the instruments used are well established with good psychometric properties, they fall short of providing a diagnosis based on clinical examination.

Most important, however, is the potential for selection bias when comparing outcomes between individuals who underwent amputation and those treated with limb salvage. If those who underwent amputation differed in important ways from those who underwent limb salvage, the validity of our results is seriously compromised. When treatments are not randomized, analytic methods such as propensity scoring can be used to balance the likelihood of receiving one treatment or the other. Unfortunately, the factors most important in predicting the likelihood of amputation - namely, the extent and severity of the injury - were not uniformly available when 
the amputation was performed prior to the patients' arrival stateside. One could argue, however, that once the limb is removed, the extent and severity of the underlying injury are not important in determining functional outcome. Put a different way, one can comfortably assume that the decision to amputate is independent of the individual's outcome given amputation. Furthermore, the injuries leading to amputation are likely to be as or more severe than those resulting in limb salvage. For this reason, the better outcomes observed among the amputees are all the more compelling.

While the characteristics of patients undergoing amputation are similar in many ways to those of patients treated with limb salvage, there may be unmeasured differences between the two treatment groups and the potential for confounding still exists. Of particular concern is the differential response rate between the amputee and limb salvage groups. While our response rate was modest $(59.2 \%)$ and similar to that in other studies of amputees [21, 23, 37, 38], individuals with an amputation were significantly more likely to participate in the study than were service members whose limbs were salvaged (64\% versus $55 \%$ ). It is difficult to speculate whether those who did not participate were better or worse off than those who did participate. More important is knowing whether the reasons for nonparticipation differed between the amputation and limb salvage groups. If patients with limb salvage are more predisposed (than amputees) to NOT participate if they are doing well, then the comparison of the results of the two groups could be compromised.

\section{Conclusion}

Major lower-limb trauma sustained in the military results in substantial long-term disability. At an average of three years postinjury, those treated with amputation appeared to have better functional outcomes than those treated with limb salvage. Caution is needed when interpreting these results as the potential for selection bias exists. Prospective studies are needed to confirm these results and to determine the role that rehabilitation protocols, ancillary services, or other external factors play in determining better or worse outcomes. At the present time, data are insufficient to support the selection of amputation over limb salvage. Rather, our results underscore the importance of addressing the post-acute-care needs of both patients treated with limb salvage and those who undergo amputation.

Conflict of interest. The authors declare the absence of conflict of interest.

\section{Reference}

1. Characterization of extremity wounds in Operation Iraqi Freedom and Operation Enduring Freedom / B. D. Owens, J. F. Kragh Jr, J. Macaitis [et al.] // J. Orthop. Trauma. - 2007. — Vol. 21 (4). P. 254-257. - DOI: 10.1097/BOT.0b013e31802f78fb.

2. Combat wounds in operation Iraqi Freedom and operation Enduring Freedom / B. D. Owens, J. F. Kragh Jr, J. C. Wenke [et al.] // J. Trauma. — 2008. — Vol. 64 (2). — P. 295-299. DOI: $10.1097 /$ TA.0b013e318163b875.

3. An analysis of outcomes of reconstruction or amputation after leg-threatening injuries / M. J. Bosse, E. J. MacKenzie, J. F. Kellam [et al.] // N. Engl. J. Med. — 2002. — Vol. 347 (24). P. 1924-1931. - DOI: 10.1056/NEJMoa012604.

4. Long-term persistence of disability following severe lowerlimb trauma. Results of a seven-year follow-up / E. J. MacKenzie, M. J. Bosse, A. N. Pollak [et al.] // J. Bone Joint Surg. Am. - 2005. - Vol. 87 (8). - P. 1801-1809. DOI: 10.2106/JBJS.E.00032.

5. Psychological distress associated with severe lower-limb injury/ M. L. McCarthy, E. J. MacKenzie, D. Edwin [et al.] // J. Bone Joint Surg. Am. — 2003. — Vol. 85 (9). - P. 1689-1697.

6. Early predictors of long-term work disability after major limb trauma / E. J. MacKenzie, M. J. Bosse, J. F. Kellam [et al.] // J. Trauma. — 2006. — Vol. 61 (3). — P. 688-694. DOI: $10.1097 / 01 . t a .0000195985 .56153 .68$.

7. Short musculoskeletal function assessment questionnaire: validity, reliability, and responsiveness / M. F. Swiontkowski, R. Engelberg, D. P. Martin, J. Agel // J. Bone Joint Surg. Am. - 1999. — Vol. 81 (9). - P. 1245-1260.

8. Paffenbarger R. S. Jr. Physical activity as an index of heart attack risk in college alumni / R. S. Paffenbarger Jr, A. L. Wing, R. T. Hyde // Am. J. Epidemiol. — 1978. - Vol. 108 (3). P. $161-175$.

9. Compendium of physical activities: an update of activity codes and MET intensities / B. E. Ainsworth, W. L. Haskell, M. C. Whitt [et al.] // Med. Sci. Sports Exerc. - 2000. Vol. 32, Suppl. 9. - P. S498-S504.

10. Physical activity and public health. A recommendation from the Centers for Disease Control and Prevention and the American College of Sports Medicine / R. R. Pate, M. Pratt, S. N. Blair [et al.] // JAMA. — 1995. — Vol. 273 (5). P. 402-407.

11. Center for Epidemiologic Studies Depression Scale: review and revision (CESD and CESD-R) / W. W. Eaton, C. Smith, M. Ybarra [et al.] // The use of psychological testing for treatment planning and outcomes assessment / Ed. M. E. Maruish. $3^{\text {rd }}$ ed. - Mahwah, NJ : Lawrence Erlbaum Associates ; 2004. - P. 363-378.

12. Assessing depression in primary medical and psychiatric practices / H. C. Schulberg, M. Saul, M. McClelland [et al.] // Arch. Gen. Psychiatry. - 1985. - Vol. 42 (12). — P. 1164-1170.

13. Forbes $\mathrm{D}$. The validity of the PTSD checklist as a measure of symptomatic change in combat-related PTSD / D. Forbes, M. Creamer, D. Biddle // Behav. Res. Ther. - 2001. Vol. 39 (8). - P. 977-986.

14. Prevalence of mental health problems and functional impairment among active component and National Guard soldiers 3 and 12 months following combat in Iraq / J. L. Thomas, J. E. Wilk, L. A. Riviere [et al.] // Arch. Gen. Psychiatry. - 2010. - Vol. 67 (6). - P. 614-623. — DOI: 10.1001/ archgenpsychiatry.2010.54.

15. Grading the severity of chronic pain / M. Von Korff, J. Ormel, F. J. Keefe, S. F. Dworkin // Pain. — 1992. — Vol. 50 (2). P. $133-149$.

16. Psychometric characteristics of the Multidimensional Scale of Perceived Social Support / G. D. Zimet, S. S. Powell, G. K. Farley [et al.] // J. Pers. Assess. — 1990. — Vol. 55 (3-4). P. 610-617. 
17. Combat duty in Iraq and Afghanistan, mental health problems, and barriers to care / C. W. Hoge, C. A. Castro, S. C. Messer [et al.] // N. Engl. J. Med. — 2004. — Vol. 351 (1). - P. 13-22. DOI: $10.1056 /$ NEJMoa040603.

18. Fracture and dislocation classification compendium - 2007 : Orthopaedic Trauma Association classification, database and outcomes committee / J. L. Marsh, T. F. Slongo, J. Agel [et al.] // J. Orthop. Trauma. - 2007. - Vol. 21, Suppl. 10. - P. S1-S133.

19. Musculoskeletal function assessment: reference values for patient and non-patient samples / R. Engelberg, D. P. Martin, J. Agel, M. F. Swiontkowski // J. Orthop. Res. - 1999. Vol. 17 (1). - P. 101-109.

20. Servicemembers and veterans with major traumatic limb loss from Vietnam war and OIF/OEF conflicts: survey methods, participants, and summary findings / G. E. Reiber, L. V. McFarland, S. Hubbard [et al.] // J. Rehabil. Res. Dev. - 2010. Vol. 47 (4). — P. 275-297. — DOI: 10.1682/JRRD.2010.01.0009.

21. Mild traumatic brain injury in U.S. Soldiers returning from Iraq / C. W. Hoge, D. McGurk, J. L. Thomas [et al.] // N. Engl. J. Med. - 2008. - Vol. 358 (5). - P. 453-463. DOI: 10.1056/NEJMoa072972.

22. Hoge C. W. Mental health problems, use of mental health services, and attrition from military service after returning from deployment to Iraq or Afghanistan / C. W. Hoge, J. L. Auchterlonie, C. S. Milliken // JAMA. - 2006. Vol. 295 (9). - P. 1023-1032. — DOI: 10.1001/jama.295.9.1023.

23. Lapierre C. B. Posttraumatic stress and depression symptoms in soldiers returning from combat operations in Iraq and Afghanistan / C. B. Lapierre, A. F. Schwegler, B. J. Labauve // J. Trauma Stress. — 2007. — Vol. 20 (6). - P. 933-943. DOI: $10.1002 /$ jts. 20278.

24. Milliken C. S. Longitudinal assessment of mental health problems among active and reserve component soldiers returning from the Iraq war / C. S. Milliken, J. L. Auchterlonie, C. W. Hoge// JAMA. - 2007. - Vol. 298 (18). - P. 2141-2148. DOI: $10.1001 /$ jama.298.18.2141.

25. Psychological correlates of battle and nonbattle injury among Operation Iraqi Freedom veterans / A. J. MacGregor, R. A. Shaffer, A. L. Dougherty [et al.] // Mil. Med. — 2009. — Vol. 174 (3). P. 224-231.

26. Posttraumatic stress and its relationship to physical health functioning in a sample of Iraq and Afghanistan War veterans seeking postdeployment VA health care / M. Jakupcak, J. Luterek, S. Hunt [et al.] // J. Nerv. Ment. Dis. — 2008. - Vol. 196 (5). P. 425 428. - DOI: 10.1097/NMD.0b013e31817108ed.

27. Bringing the war back home: mental health disorders among 103,788 US veterans returning from Iraq and Afghanistan seen at Department of Veterans Affairs facilities / K. H. Seal, D. Bertenthal, C. R. Miner [et al.] // Arch. Intern. Med. — 2007. -
Vol. 167 (5). - P. 476-482. - DOI: 10.1001/archinte.167.5.476

28. Posttraumatic stress disorder and depression in battle-injured soldiers / T. A. Grieger, S. J. Cozza, R. J. Ursano [et al.] // Am. J. Psychiatry. - 2006. — Vol. 163 (10). — P. 1777-1783 ; quiz 1860. - DOI: 10.1176/ajp.2006.163.10.1777.

29. Tanielian T. Invisible wounds of war: psychological and cognitive injuries, their consequences and services to assist recovery / Eds. T. Tanielian, L. H. Jaycox. - Santa Monica, CA : RAND Corporation ; 2008.

30. PTSD, combat injury, and headache in Veterans Returning from Iraq/Afghanistan / N. Afari, L. H. Harder, N. J. Madra [et al.] // Headache. — 2009. — Vol. 49 (9). — P. 1267-1276. DOI: $10.1111 /$ j.1526-4610.2009.01517.x.

31. Neuropsy-chological outcomes of army personnel following deployment to the Iraq war / J. J. Vasterling, S. P. Proctor, P. Amoroso [et al.] // JAMA. — 2006. - Vol. 296 (5). P. 519-529. — DOI: 10.1001/jama.296.5.519.

32. A prospective study of depression following combat deployment in support of the wars in Iraq and Afghanistan / T. S. Wells, C. A. LeardMann, S. O. Fortuna [et al.] // Am. J. Public. Health. — 2010. — Vol. 100 (1). - P. 90-99. — DOI: 10.2105/ AJPH.2008.155432.

33. Health-care costs associated with amputation or reconstruction of a limb-threatening injury / E. J. MacKenzie, A. S. Jones, M. J. Bosse, [et al.] // J. Bone Joint Surg. Am. — 2007. Vol. 89 (8). - P. 1685-1692. — DOI: 10.2106/JBJS.F.01350.

34. Energy expenditure and activity of transfemoral amputees using mechanical and microprocessor-controlled prosthetic knees / K R. Kaufman, J. A. Levine, R. H. Brey [et al.] // Arch. Phys. Med. Rehabil. — 2008. - Vol. 89 (7). - P. 1380-1385. DOI: 10.1016/j.apmr.2007.11.053.

35. Prosthetic intervention effects on activity of lower-extremity amputees / G. K. Klute, J. S. Berge, M. S. Orendurff [et al.] // Arch. Phys. Med. Rehabil. — 2006. - Vol. 87 (5). - P. 717-722. DOI: 10.1016/j.apmr.2006.02.007.

36. Prescription of prosthetic ankle-foot mechanisms after lower limb amputation / C. Hofstad, H. Linde, J. Limbeek, K. Postema // Cochrane Database Syst. Rev. - 2004. — № 1. - CD003978. DOI: 10.1002/14651858.CD003978.pub2.

37. The study of reproductive outcome and the health of offspring of UK veterans of the Gulf war: methods and description of the study population / N. Maconochie, P. Doyle, G. Davies [et al.] // BMC Public Health. - 2003. — Vol. 3. - Article 4. DOI: $10.1186 / 1471-2458-3-4$.

38. Cumming J. C. Prosthetic rehabilitation for older dysvascular people following a unilateral transfemoral amputation / J. C. Cumming, S. Barr, T. E. Howe // Cochrane Database Syst. Rev. - 2006. № 4. - CD005260. — DOI: 10.1002/14651858.CD005260.pub2.

\title{
СРАВНИТЕЛЬНЫЕ РЕЗУЛЬТАТЫ АМПУТАЦИЙ И ОРГАНОСОХРАНЯЮЩИХ ОПЕРАЦИЙ ПОСЛЕ ВОЕННЫХ ТРАВМ НИЖНИХ КОНЕЧНОСТЕЙ
}

\author{
R. A. Hayda ${ }^{1}$, W. C. Doukas ${ }^{2}$, R. C. Andersen ${ }^{3}$, J. R. Ficke ${ }^{4}$ \\ ${ }^{1}$ Род Айленд Госпиталь, Браун Университет, Провиденс. США \\ ${ }^{2}$ Объединенный госпитальный ортопедический центр, Бриджпорт. США \\ ${ }^{3}$ Национальный Военный Медицинский Центр Вальтера Рида, Вашингтон. США \\ ${ }^{4}$ Сан Антонио Военный Медицинский Центр, Форт Сэм Хьюстон. США
}

$\triangle$ Roman A. Hayda, MD: Roman_Hayda@brown.edu 